\title{
Training and Development from the management's viewpoint: a case study in the food sector
}

\section{Treinamento e Desenvolvimento sob a ótica dos gestores: um estudo de cado no ramo alimentício}

\author{
Evelin Panis Gil Tecnóloga em Gestão de Recursos Humanos. Instituto Federal do Mato Grosso (IFMT) Campus \\ Alta Floresta - Brasil. evelinpanis@hotmail.com \\ Lenoir Hoeckesfeld Doutorando em Administração. Universidade do Vale do Itajaí (UNIVALI) e Instituto Federal do \\ Mato Grosso (IFMT) Campus Alta Floresta - Brasil. leno.adm@gmail.com \\ Luiz Henrique da Silva Mestrando em Administração. Universidade do Vale do Itajaí (UNIVALI) - Brasil. \\ luizhenrique301@hotmail.com \\ Christiane Mendes Drozdek Pereira Doutoranda em Administração. Universidade do Vale do Itajaí (UNIVALI) - Brasil. \\ christiane.pereira2006@gmail.com
}

\begin{abstract}
Faced with a competitive economic scenario, organizations use Training and Development (T\&D) techniques to increase the performance of people, develop skills and acquire new knowledge that aim to increase the satisfaction of their human capital, preparing them for the challenges and changes that may occur in the social and work environment. This article sought to identify possibilities for improvements in T\&D in a food industry organization from the perspective of its managers. It is a qualitative and descriptive research, carried out in a food company in the city of Alta Floresta (Mato Grosso). The instrument used for data collection was the semistructured interview with managers of the Human Resources (HR) area, in addition to documents made available by the company. For data analysis, content analysis with thematic categorization was used. As a result, the need for investments in the training of HR managers, leaders and, mainly, employees of the industrial base were identified. As for leadership development, it was detected that there is the need to work on communication practices between leaders and subordinates, aiming at improving working relationships. Therefore, the importance of thinking about T\&D actions in an integrated way with Corporate Education is considered, with the purpose of enabling employees to develop them, in addition to meeting the strategic and operational needs of the organization.
\end{abstract}

Keywords: Training. Development. Corporate Education. Human Capital.

\section{RESUMO}

Diante de um cenário econômico competitivo, as organizações utilizam-se de técnicas de Treinamento e Desenvolvimento (T\&D) para ampliar o desempenho de pessoas, desenvolver competências e adquirir novos conhecimentos que visem aumentar a satisfação do seu capital humano, preparando-os para os desafios e mudanças que possam ocorrer no ambiente social e laboral. $O$ presente artigo buscou identificar possibilidades de melhorias no T\&D em uma organização do ramo alimentício a partir da percepção de seus gestores. Trata-se de uma pesquisa qualitativa e descritiva, realizada em uma empresa do ramo alimentício da cidade de Alta Floresta (Mato Grosso). $\mathrm{O}$ instrumento para coleta de dados utilizado foi a entrevista semiestruturada aplicada com gestores da área de Recursos Humanos (RH), além de documentos disponibilizados pela empresa. Para análise dos dados foi utilizada a análise de conteúdo com categorização temática. Como resultado identificou-se a necessidade de investimentos na capacitação dos gestores de $\mathrm{RH}$, líderes e principalmente, aos colaboradores da base industrial. Quanto ao desenvolvimento de lideranças, percebeu-se a necessidade de trabalhar práticas de comunicação entre líder e liderados, visando a melhoria das relações de trabalho. Considera-se, portanto, a importância de se pensar em ações de T\&D de forma integrada com a Educação Corporativa, com o propósito de possibilitar aos colaboradores o seu desenvolvimento, além de, atender as necessidades estratégicas e operacionais da organização.

Palavras-chave: Treinamento. Desenvolvimento. Educação Corporativa. Capital Humano. 


\section{INTRODUCTION}

Professionals who work in the Training and Development (T\&D) area have undergone considerable changes in their practices in recent decades, once this process is directly related to professional and organizational performance. The increase in technology has brought a drastic reduction between time and development, when considering the emerging needs for adaptation to environments, requiring rapid changes and skills adaptation, knowledge and learning processes (Barrat-Pugh, Hodge, \& Smith, 2018).

$T \& D$ emerged in organizations as a source of training and improvement of the skills of employees (Macena Neto \& Mota, 2017), requiring investment by organizations, who viewed Corporate Education (CE) as an alternative. CE is considered a personalized strategy, which enables the necessary change process to develop skills, improve processes, enhance intellectual capacity, creativity and innovation of human capital (Menegon \& Zambarda, 2019).

The justification for this research has as its main point a theoretical and empirical contribution on the importance of T\&D processes and the verification of difficulties found in organizations in relation to these processes. Research shows that T\&D improves the company's image and is a way to raise awareness among employees about ethical and moral issues, which lead individuals to reflect on improper conduct in the workplace (Hanapiyah, Daud, Abdullah, \& Sanusi, 2018), providing a change in behavior in the execution of their work activities and in organizational practices (Hardy III, Day, \& Arthur Junior, 2018). Another aspect that emphasizes the relevance of the research is the importance of the food sector for the country. In 2018, the sector was responsible for handling $\mathrm{R} \$ 524.7$ billion through industry distribution channels. In exports, there was a turnover of US $\$ 239.9$ billion, in 2017 it generated 35.8 million jobs (Brazil, 2019).

In view of the above, considering the relevance of the proposed theme and the need for companies to qualify their employees, this research aims to identify possibilities for improvements in training and development in a food business organization from the perspective of its managers, seeking to contribute to the reflection of the theme as a topic of interest in organizations and universities.

To address the topic of T\&D, this research initially presents the importance of human capital in organizations, training, development and corporate education. Then, the methodological procedures used for this study. Finally, the main results of this research are presented in a table with a summary of the main points addressed and suggestions for improvements, and the final considerations.

\section{THEORETICAL FOUNDATION}

This section presents the main theoretical contributions that supported this research.

\subsection{Organizational Human Capital}

From the economic point of view, the concept of the word capital refers to wealth and assets available. Expanding to a vision of the Human Capital Theory, people come to be considered a form of capital for development, their learning capacity being a value compared to other organizational resources. This theory seeks to explain that profit from education and training are investments to prepare the workforce, increase the productivity of individuals and organization, and are necessary for social development (Nafukho, Hairston, \& Brooks, 2004).

In this sense, the Human Capital Theory is characterized by the transformation of an individual, through training and information, contributing to organizational profitability and productivity, made possible by the recognition of their skills and knowledge (Karolczak \& Souza, 2017). In addition, Azevedo (2013) states that it is up to the organization to value this capital and to align human needs and resources, so that they allow individual growth and converge with organizational development, generating continuous renewal through the absorption of new knowledge and expansion of the innovation process. 
Human capital can be understood as the total sum of individual competences (knowledge, skills, talents, attitudes, behaviors), which make up the team and add value to the organization and the capacity of these individuals to adapt to the various situations generated by the internal or external environment. (Scantamburlo, Delgado, Cavalheiro, \& Kremer, 2019), which may favor productivity, innovation and corporate performance (Bortoluzzi, Genari, \& Macke, 2018). Amorim, Cruz, Sarsur and Fisher (2015), characterize human capital by its degree of formation, according to the group it belongs to and its ability to identify the elements that permeate and direct to interests, ethical and social aspects. The authors also highlight that the low level of education influences the judgment and decision capacity of individuals.

Therefore, each organizational context requires different needs, skills and professionals' capacities, which directs the actions and initiatives adopted for the T\&D strategies. Individuals' careers, strategy and organizational development, portray a dynamic and proactive reality of professionals working with T\&D and the connection of all these factors for business growth, in addition to the requirement of an objective and subjective ability to deal with different organizational scenarios (Barrat-Pugh, Hodge, \& Smith, 2018).

\subsection{Training}

Training is exposed as the understanding of the organizational culture, through which it aims to transmit, reinforce knowledge, skills or attitudes related to the execution of tasks or to improvement at work (Bagattoli \& Muller, 2016). In this perspective, Marras (2017b) characterizes it as a learning process that promotes the acquisition of skills, rules, and attitudes that culminate in adjusting the peculiarities of employees to the demands of each function.

As a human resource development tool, training improves the capacities and skills of organizational human capital. What is expected from the training is to find and overcome deficiencies in the performance of employees, leaving them prepared to take on new assignments or adapt them to new technologies in the work environment (Froehlich \& Scherer, 2013; Macena Neto \& Mota, 2017). The training used as a continuous process, collaborates in the development of people, guides to decision making, improves interpersonal relationships and opens a new vision, making individuals more creative and innovative (Bagattoli \& Muller, 2016).

Following this conception, Marras (2017a) ponders some fundamental points objectified by the training, which are: to enable employees to perform different tasks inherent to the organization; provide the continuous development of the individual; increase productivity; improve the quality of results; reduce the rate of accidents at work; improve organizational climate; increase employee motivation; reduce absenteeism; and reduce company turnover. Also according to Marras (2017a), the necessary steps to apply training that brings good results are: diagnosis - verification of training needs to be addressed in the long and medium term; training schedule - creation of the plan that will attend the detected deficiencies; implementation / execution - implementation and management of the training program; and evaluation - examining the results achieved after the training.

Therefore, there is a need for continuous improvement of human capital, since organizations seek to keep their processes efficient and effective, which requires qualified employees. Training becomes advantageous because it has the ability to subsidize the development of people, being responsible for positive aspects that permeate the process of development and growth of the organization and its collaborators. Thus, the higher the training level, the better the results obtained (Bagattoli \& Muller, 2016).

\subsection{Development}

In the view of Volpe and Lorusso (2009) the development of people presupposes a constant improvement, characterized by the variation in the evolution, growth, stimulus and progress of new technologies. For the individual to develop, it is necessary to invest and capture new knowledge capable of boosting his career. It is through the learning process that people qualify, optimize their skills, change their attitudes and become functional pieces with the power to achieve the quality desired by organizations, which 
in turn, need to stimulate and support the continuous development of employees to preserve their competitive advantage (Leite \& Loft, 2013; Dutra, Dutra, \& Dutra, 2017).

Development aims to analyze, identify and contribute to the potential and capacity of human capital. It is a process of self-identification and management, which allows the evolution of a current state for the acquisition of skills, knowledge and future competence necessary for the organizational environment (Jalloh, Habib, \& Sesay, 2015). The management and development of human capital goes through a process of identifying new practices, centered on self-development, in social and collective forms, through a network environment in which knowledge is generated and evolves, based on needs, which ends up requiring more psychomotor and cognitive skills (Barrat-Pugh, Hodge, \& Smith, 2018).

For development to take place, training must effectively achieve the results proposed by the organization. People develop through training and better results are achieved when the proposal to carry out the training is consistent with the employee's desire to learn and improve. The development of people in the organization is considered a set of learning experiences, with the purpose of intentionally improving human performance or growth (Bagattoli \& Muller, 2016).

Through training, development and education, professional and personal aspects are modified, such as changing behaviors, opening new horizons and the possibility of spreading more positive attitudes. Organizations must be aware that for the full development of human capital there is a need not only for training, but for education (Bagattoli \& Muller, 2016).

\subsection{Corporative Education}

Considering that the organizational environments go through different scenarios during their consolidation, whether at the national or international level, they require the implementation of actions that promote the learning of individuals in a continuous way that allows the planning and adaptation to the business needs. Faced with an increasingly strategic perspective, traditional T\&D programs no longer meet the new requirements in the short, medium and long term. Within this innovative and dynamic context, CE is presented, which deals with the interaction between teaching and learning in a continuous way, promoting the development of competences, which support the maintenance of competitive advantage, moving from the individual focus to the business perspective (Toledo \& Domingues, 2018; Silva, Fonseca, Silva, Portugal Junior, \& Piurcosky, 2018).

In organizations in general, CE is linked to people management and it is fundamental in the integrative process between people and organizations, with the objective of elevating and valuing the individual, improving the quality of people, teams, processes, products, aiming to assist in strategies maintenance and attraction of professionals (Amorim, et al., 2015). CE has a different focus from traditional education. It proposes a generic, comprehensive, theoretical and methodological training, as it defines a learning path focused on the needs of the organization (Rosini, Alves, \& Alves, 2018).

Souza and Ziviani (2012) highlight three fundamental factors for the CE process: - theory and practice: higher education is responsible for the theoretical basis of the professionals, but there are difficulties in using theory immediately in practice; - adequate training: it is necessary to respect the reality of the organization, which does not always require higher education, and may require specific training; - constant training: training must be continuous, due to the rapid need for new knowledge.

Toledo and Domingues (2018) point out that CE increases the value of human capital, the market value of organizations and, consequently, competitiveness. This new view on T\&D programs allows the development of the individual as a whole, generating stimuli for the dissemination of knowledge, innovation and creativity. CE is part of a process of preparing individuals for social and collective interaction, through educational actions, raising the intellectual, physical, spiritual, aesthetic and affective potential, influencing the business value chain (Souza \& Ziviani, 2012). 


\section{RESEARCH METHOD}

This study is characterized as qualitative because it is an adequate way to understand the nature of a social phenomenon, its contexts or environments in which the participants are inserted, in an attempt to understand in detail, the meanings and situational characteristics presented (Creswell, 2014). The research is classified as descriptive because it favors the understanding of behaviors from the perspective of those involved in the investigation (Zanette, 2017). It is understood that the most appropriate method to answer the research problem is the case study, as the objective of this research is to identify the perception of the managers of an organization in the food industry about the importance of applying T\&D to its employees. The case study "investigates a contemporary phenomenon in depth and in its real-world context, especially when the boundaries between phenomenon and context may not be clearly evident" (Yin, 2015, p. 17).

The research was carried out with 702 employees in a food company located in the city of Alta Floresta, state of Mato Grosso (MT), Brazil. Semi-structured interviews were conducted with three managers in the Human Resources (HR) area of the company, in person and with an average duration of 40 minutes each. The script for the semi-structured interview was prepared based on Souza, Kanaane and Fernandez (2015) and Botoli (2017). The interviewees were chosen based on their time of service in the company and the functions performed being linked to the HR area. Chart 1 presents the interviewees' profile:

\section{Chart 1.}

Respondents profile

\begin{tabular}{|l|c|l|c|c|}
\hline \multicolumn{1}{|c|}{ Title } & Gender & Level of education & $\begin{array}{c}\text { Years in the } \\
\text { company }\end{array}$ & $\begin{array}{c}\text { Indentification in } \\
\text { the analisys }\end{array}$ \\
\hline HR Coordinator & M & College Degree & 1,10 years & R1 \\
\hline HR Analyst & F & College Degree & 2,5 years & R2 \\
\hline Planning Supervisor & M & High School & 9 years & R3 \\
\hline
\end{tabular}

Source: Developed by the authors (2020).

In this research, primary and secondary data were used. The collection of primary data was carried out through semi-structured interviews applied to the three managers of the organization, recorded on audio and transcribed in full to preserve the quality of the content. Interviews are one of the most important sources of information in a case study, as they can provide insight into issues or actions, as well as, identify other relevant sources of evidence (Yin, 2015). Subsequently, the data were organized in the form of text and treated through content analysis with thematic categorization involving pre-analysis, exploration of the material and treatment of the results (Bardin, 2011).

Secondary data were collected in documents made available by the company regarding its organizational characteristics, as well as a report with quantitative data on the staff. Document analysis represents an important contribution to studies as it is a rich source of data. The examination of materials allows you to analyze documents that have not yet been seen or to re-examine them in order to produce new knowledge (Godoy, 1995; Sá-Silva, Almeida, \& Guindani, 2009).

\section{ANALYSIS OF RESULTS}

The company studied is considered to be large, it is located in the city of Alta Floresta - MT and has less than 10 years of activity in the food industry. Its secondary economic activities are: fast delivery services; processing of slaughter by-products; provision of food prepared mainly for household consumption; and meat products processing.

The company has a system called AVD for people management. The AVD system in addition to being an important management tool, is a philosophy for the company. It aims to develop and monitor the professional growth of employees through demonstrated behaviors and achieved results. Regarding the 
profile of the company's employees in education level analysis through data provided by the HR Department, it was visible that the vast majority have a low level of education, only $3 \%$ are graduates, and most of these, work in management/administrative level. Jalloh, Habib and Sesay (2015), emphasize that individuals must be motivated to learn, with the role of management being fundamental for the science of current reality and the needs for knowledge, skills and competences, making it essential to understand the usefulness of learning.

Regarding the forms of diagnosis of training needs, it was understood that the company uses several actions in its daily life to try to identify possible deficiencies in its structure. Annual organizational climate surveys are carried out in order to leverage and refine the HR sector and thus, improvements for the company are achieved. R2 explains that training needs are "verified in weekly leadership meetings, in termination interviews, during feedbacks, in addition to the DSD (Daily Safety Dialogue) and coffee-breaks with the employee, where a relaxed chat aims to collect information about possible deficiencies". R1 adds that such information is also obtained "through the factory climate, noise, and when this begins to be perceived; it starts to be exposed in the meetings of people that occur every Monday after work with supervisors".

The trainings have a positive influence on the employees' commitment, they also reflect on the turnover rates of the organizations. When these actions are combined with the support and monitoring of management, in aspects such as safety, career and work execution, it allows for increased involvement of employees in T\&D programs, as well as contributing to the improvement of individuals' physical and mental well-being and has an impact on engagement, productivity and operational effectiveness (Rawashdeh \& Tamimi, 2019).

In the last two years, regarding the execution of T\&D programs, the forms of application and those responsible, it was observed that the company has monthly training policies for leaders and a wide range of online courses for managers. The online courses according to Silva, Gomes Junior, Valdati, Willerding and Lapolli (2017), have the advantage of instructing individually according to the compass of each employee, because their feedback is instantaneous, there is the possibility of practice, monitoring and diagnosis, in addition to the constant guidance and assessment of learning. Menegon and Zambarda (2019) complement that an organization that learns is one that is able to modify its behavior to create, acquire, interpret, transform and retain knowledge and insights.

In the company, training for specific functions such as engineers, for example, is carried out sporadically, mainly at the group's headquarters in São Paulo, normally related to job security, communication, inclusion of people with disabilities. In addition to the on-site training, normally transmitted by the managers themselves to the base employees, confirmed by R3 when stating that "what mostly happens are demonstrative technical visits, lectures, training with a manager on site". $\mathrm{R} 1$ also explains that, "DSD takes place every day, where managers take time at the beginning, middle or end of production, according to the convenience of their and the team's schedule, to deal with issues related to safety at work and management" What is observed in this approach of the interviewees is that the company's actions are related to $C E$, since it provides continuous learning without necessarily being linked to a classroom. In this new learning model, knowledge is in the availability of accessible resources that enable learning anytime and anywhere (Silva, Fonseca, Silva, Portugal Júnior, Piurcosky, 2018).

The presentation by HR analyst R2 clarifies that:

For example, for leaders and managers, there is the Universidade da Carne, where they offer on average 50 mandatory courses, for each sector, available online via intranet. Among the contents covered, there are matters on management and internal procedures and specific content required by market demand. Monthly and in person, there is the Leadership Forum and other small training sessions, which are my responsibility, the HR analyst and the HR Coordinator. There is also a development program called Bank of Talents that takes place annually. Basically, supervisory leaders appoint a collaborator who performs monitoring in order to make him a future supervisor. He will have an online class, a face-to-face class and a practical class. At the end of the program, this employee is graduated and if considered fit, he is available to take on the position of supervisor in the database of the entire group, not just for the branch. And when the employee has no 
intention or possibility of moving to another region or unit, there is the Internal Talent, which works along the same lines as the Talent Bank program.

However, the planning supervisor, R3, clarifies that "the company still has a great deficiency in developing new leaders. There is a great challenge in developing leaders and there is little interest on the part of the employee to develop. Leaders have difficulties communicating with their followers". Thus, there is a need for more T\&D actions, since coordinators, supervisors, managers and leaders are responsible for training base employees, and according to Froehlich and Scherer (2013),for the employee to take on a new position, adequate conditions are required. The company needs to apply the process of developing people as part of its management strategies, in which its fundamentals start to adjust the reorganization of the work, the type of worker and the work relations. This need becomes more evident after R3 mentions that:

Today, unfortunately, these actions are usually developed after the problem, in a corrective way. There is often a complaint by the customer and from there it is verified what happened and steps are taken to prevent the problem from recurring. The correction of a problem pointed out by a customer is an obligation of the company. There are rules that must be followed so that such problem does not happen again. But there is a lack of preventive actions on the part of the company. There is a lack of pro-active actions to prevent possible problems.

With such reports about T\&D programs, it is evident that there is a failure of the organization in not paying attention to the adequate qualification of its collaborators, mainly the ones at the base, that is, the socalled "factory floor" workers. Having already been illustrated by Froehlich and Scherer (2013) that training is a way to develop employees, not only able to remedy deficiencies, but also an essential tool to refine the capacities and skills of the organization's employees. Thus, despite the offer of monthly courses to employees at management levels, there are still deficiencies in training and transfer of knowledge to base workers. Macena Neto and Mota (2017) show that the perception of coaches, instructors, tutors, in addition to the instruments used and course time, are also extremely relevant in the approval or not of a training.

The $\mathrm{R} 1$ reinforces "what the manager learns in class, in the course, he applies everything to his followers on a daily basis. But specifically, for floor operators, there is very little training". In addition, the HR analyst, R2, emphasizes the low investment in his own training, saying that "the person responsible for T\&D must be prepared for the role and must also be very well developed and trained to be able to captivate his team". In this same sense, R3 also includes that:

The company has good internal training programs, but it lacks time and planning to do time management versus production for the correct application of such training. It is necessary to train and teach even more about the importance of its function, notions of product quality, safety. In other words, there are basic presentation and integration courses, but there is a certain deficiency in specific courses, technical courses for base operators. The most worrying issue is the lack of qualified labor in the region.

Consequently, R1 highlights that:

It was noticed that the leaders are not able to fulfill the demand and also answer some questions, so training is being developed to train these leaders who work directly with employees at the base. They will be developed in terms of people management, product quality, work safety, labor relations. Themes that will be added to other existing leadership development programs. The intention is to qualify the leaders who are below the supervisors, and who are in direct contact with the base workers. And in addition to looking for someone interested in growing and who wants to leave the production line to take on supervision. In the past, production and quantity were mainly aimed at, and today, you want leaders 
who deliver production, but also know how to deal with people, seeking to improve contact, dialogue, a better relationship with the base.

Regarding training aimed at new employees, the use of new equipment and necessary procedures, it was noted that the company considers training the Integration Program applied to new members of the organization. R1 notes that "training takes place on a daily basis through the transfer of information by the managers of each sector". The integration program, for Marras (2009) is fundamental, as it seeks to help the employee adapt and mold to the social and physical environment of the new company to which he will perform his tasks. The HR coordinator, R1, explained that:

Depending on the area of activity of the new employee, the integration takes place, normally lasting three days. On the first day, information related to the personal department is passed, such as benefits, meal times, menu, obligations, occupational health (periodic exams, consultations, mandatory questions), management information, such as product quality requirements and how production is calculated. An institutional video is shown to present the company, regarding size and production capacity. Finally, the workplace safety team dedicates a day and a half or two to new employees, who in fact undergo technical training to perform their duties in places of height and also in confined space.They spend half a day in the classroom and then leave for field instruction (practical part). For new hires who will perform functions that demand less risk, there is a team of experienced workers, who are called 'godparents', who welcome them, present the workspace and colleagues. These godparents are responsible for guiding and accompanying these new employees in all environments, both in the development of their tasks, and to take them to in-site restaurants, to locker rooms(changing facilities), entry and exit, during the trial period. And when new machines are deployed in production and industry, at the time of negotiating the purchase of such equipment, training is also negotiated by the supplier company that comes to the site to train the employees who will handle it. In addition, it is reinforced by the managers, considering each new tool, new machine, all the safety part for the operation of this equipment.

On such examples of training applied in the workplace, Araújo and Garcia (2009) consider it convenient to present new technologies, new techniques and different methodologies. Corroborating to the findings of Froehlich and Scherer (2013) that point out the relevance of the company presenting as a strategy for the transfer of knowledge, training in the workplace (on the job), where employees are placed in real work situations, becoming productive quickly, that is, they learn by doing. In this perspective, Silva, Gomes Junior, Valdati, Willerding e Lapolli (2017), add that such a practice is advantageous, since there are fewer problems due to the fact that the employee is trained in the physical and social environment that they will work in, facilitates the assessment of the employee's behavior already at their workplace. It is worth emphasizing the importance of management and performance evaluation and the skills of employees, given that an ineffective process results in challenges and consequences related to human capital, such as demotivation and lack of commitment, therefore, this process must be mediated by people management (Otoo, 2018).

However, R3 stresses that:

There is a lot to be done, because even with the three days of integration with the new hires, there is still a lack of knowledge to start working, since people are hired with little or no experience for the function and after they start the job, there is no more time available for the correct teaching and passing on more information.

As for the use of new technologies and updating of procedures in the company, it was understood that in compliance with NRs (industry regulatory standards), and according to R3, "always aiming to optimize processes, optimize manpower, reduce costs", the company frequently deploys new technologies and procedures, especially on the production line, so it is necessary to apply technical training to qualify employees 
to handle such equipment. A fact reinforced by Macena Neto and Mota (2017) in which they describe that what is expected from training is to find and overcome shortcomings in the performance of employees, leaving them prepared to take on new assignments or adapt them to new technologies in the work environment. In relation to this theme, $\mathrm{R} 1$ mentions that:

The company has a team of corporate employees working on what can be improved in the production line, such as, for example, the machines that transport the bovine carcass, the conveyor belts, height adjustment, width, speed of the machines according to the employee who operates it. There are also vacuum machines for meat packaging. Usually there are annual improvements, but even so, I still believe that we are below the desired level compared to the market; there are competitors that have more advanced technologies.

Finally, with regard to T\&D in the organization, it stands out that managers realize that employees feel the need for training and qualification, and that the company could make greater investments in this area. Although there are several methods considered "training" and applied to the daily life of the company, most of them cover only the technical part and the routines. According to R1, "the existing guidelines, transmitted by the managers cover only the technical part for the development of their functions and not for the personal development of employees". R3, on the other hand, states "that there could be a partnership, an interaction between the company and the municipal management to think about qualification programs, mainly the technical improvement of labor, since the company employs an average of 700 people directly in the region". More specifically, R2 states that:

[...] they feel the need, because whenever there is any type of free training, open to any public or sector, the number of adhesions and demand is very high. But all of this requires a lot of investment in materials and physical structure. For example, there is no adequate space in the unit, the current meeting room is small. And although there is a partnership between the company and Secitec (State Department of Science and Technology), the location of the company and the lack of transportation and time practically make such training impossible. The HR sector understands the investment deficiency, since the need for training is immense, also because almost $100 \%$ of the hires for base operators are from people with little or no experience, due to their labor cost, and due to the deficiency in unit communication. We also know that the motivation factor is extremely important for the smooth running of the organization, so it is necessary to invest more in T\&D to make them feel more included and participating in the organization. Otherwise, any job offers, even with a minimum wage difference, will continue to get them out of here. It has been researched and found that the biggest cause of turnover is the lack of motivation, and the lack of interaction with colleagues and leaders.

With regard to performance evaluation, it is understood that it has the role of verifying the level of performance and commitment of the internal public, thus becoming a tool for the classification of unproductive cases and the improvement of established talents. In accordance with this approach, there are some possibilities that Gil (1994) highlights as: degree of contribution to the company; if there is a higher than expected qualification; the contribution of training programs; stimulating self-knowledge and selfdevelopment; the staff profile; and data for remuneration and promotion. When there are no real conditions to make an objective assessment, it is necessary to set goals in advance that lead to results that can be observed or indirect conclusions that support the choice, to confirm whether the cost-benefit link was reached or not (Lacombe, 2011). Therefore, the company uses a tool called AVD, it is a performance management program, to monitor and recognize the difficulties, potential and needs of the employee. R2 defends how to evaluate and recognize the work of employees, by saying that: 
The company considers the highlights of the company. It depends on the individual performance of the employee. The company has two programs, an annual that is the Highlight in Workplace Safety where the highlights are rewarded with awards in moments of relaxation, such as in the cafeteria in front of coworkers, and another quarterly which is the People who Work where they compete with other highlights, which are evaluated by their managers and they also receive awards. Besides, of course, professional growth through promotions and salary increases.

However, according to R1, "there is no specific investment applied directly, but there are skills and abilities of talents that stand out through internal programs and that naturally start to grow and reach new positions within the company". Considering the reports on performance evaluation, it was not clear how to evaluate the results of T\&D programs in the company. The material provided by the HR department, the AVD, analyzes and evaluates the performance of previously selected employees for standing out in their position, with the lack of a diagnosis of the result of the training applied in the organization.

Thus, it can be seen that even with some management failures, managers agree that the company helps the professional that stands out and intends to grow within the organization. Naturally and due to the fact that many inexperienced individuals are hired, the outstanding employee gradually occupies larger/better positions. It was mentioned in the statements that the company has an example of an employee who entered the lowest level and who now occupies a management position.

However, there is a feeling of concern of the managers participating in the study with the training of workers in the production base, as they suggest greater investment for the sector in the technical, professional, personal and motivational aspect. The R1 adds that "the lack of time, charging for more production ends up preventing greater attention from the base operators. Because even with the 'cascading' (transmission) of knowledge from the manager to the operators, it would be necessary to invest more and directly for these operators". R3, on the other hand, adds that, "the suggestion would not be just for new courses or training, but also the improvement and the most effective and technical application for better use of the training that already exists". Such observation stresses the vision of Lacombe (2011), in which he mentions that nonplanning generates waste such as people in the wrong places, inefficient training and mismanagement of teams, thus generating, motivation and loss of talent.

In view of the responsibility for financial resources and people development, the management area must be attentive to organizational planning, considering that human capital is one of the main assets for achieving competitiveness. Attention to $T \& D$ and $C E$ actions is essential to promote the development of competences, skills and knowledge demanded by the business, as well as, for motivation, adaptation to new technologies and techniques for the execution of work activities (Rawashdeh \& Tamini, 2019).

In the view of managers, the results of good training add value to business result. R1 reports that "as soon as there are trained, motivated, qualified people and a good organizational climate, the good results appear". R2's statement is that "training and development are extremely important for the business. A trained person becomes more motivated, more capable". In this sense, Ivancevich (2008) presents motivation as an internal condition that produces energy to achieve goals, and at work, this turns to the achievement of private and corporate purposes. The motivation of organizations to apply training is the return on investment that the employee will give the organization after acquiring new knowledge (Lacombe, 2011).

Chart 2 presents a summary of the main notes perceived and addressed by managers, as well as, what can be improved. 
Chart 2.

Summary of the main points addressed and suggestions for improvement.

\begin{tabular}{|l|l|l|}
\hline \multicolumn{1}{|c|}{ Subject: } & \multicolumn{1}{c|}{ What happens: } & \multicolumn{1}{c|}{ What can be improved: } \\
Diagnosis & $\begin{array}{l}\text { The information is collected in different } \\
\text { ways in the company's daily routine and } \\
\text { through an annual organizational climate } \\
\text { survey. }\end{array}$ & $\begin{array}{l}\text { A greater focus can be placed on the needs } \\
\text { of base workers. }\end{array}$ \\
\hline T\&D Programs & $\begin{array}{l}\text { Formal T\&D programs are offered } \\
\text { basically to leaders, specialists and HR } \\
\text { analysts, being understood as specialists: } \\
\text { buyer, engineer, salesperson, consultant, } \\
\text { lawyers. }\end{array}$ & $\begin{array}{l}\text { More training can be offered to train HR } \\
\text { managers; } \\
\text { More relevance can be given to leadership } \\
\text { training courses, with focus on practices for } \\
\text { more efficient and motivational internal } \\
\text { communication; } \\
\text { More training and forms of development } \\
\text { can be offered to base workers. }\end{array}$ \\
\hline $\begin{array}{l}\text { T\&D } \\
\text { Application }\end{array}$ & $\begin{array}{l}\text { Online and in-person courses are } \\
\text { available for managers, leaders and } \\
\text { specialists at the unit or at the group } \\
\text { headquarters. For workers in the } \\
\text { operational base, information and } \\
\text { knowledge are transmitted by immediate } \\
\text { managers and, as the case may be, by } \\
\text { companies responsible for implementing } \\
\text { new equipment in the industry. }\end{array}$ & $\begin{array}{l}\text { More training and forms of development } \\
\text { and self-development can be offered to } \\
\text { leaders and base workers to make them } \\
\text { feel more recognized and motivated when } \\
\text { performing their daily tasks; } \\
\text { It could be partnered with municipal } \\
\text { agencies to implement technical } \\
\text { qualification courses in the area. }\end{array}$ \\
\hline $\begin{array}{l}\text { Performance } \\
\text { Evaluation }\end{array}$ & $\begin{array}{l}\text { The performance evaluation is made } \\
\text { through the AVD tool, which evaluates } \\
\text { the employees that stand out in the } \\
\text { development of their daily tasks. }\end{array}$ & $\begin{array}{l}\text { (Observations regarding forms of } \\
\text { performance evaluation were limited to } \\
\text { the AVD tool). }\end{array}$ \\
\hline
\end{tabular}

Source: Developed by the authors (2020).

Based on the notes, it is observed that some points can be improved in the current plan in the organization's T\&D area with the intention of improving possible weaknesses and making the HR department more consistent with the organizational strategy. It is noteworthy that such suggestions are considered / practiced during office hours. Therefore, it is suggested: a) training and strategic direction of the focus of the people analyst (HR analyst) also for issues that lead to greater human development, and not just for routine issues and bureaucratic procedures; b) greater investment in T\&D capable of improving the skills and competences of leaders, especially with regard to negotiations and direct interaction with employees, insofar as it should facilitate the application of T\&D content; c) investment in physical structure suitable for the unit; d) greater emphasis on technical training to increase the capacity and self-confidence of employees; e) promoting moments of socialization between leaders and teams; $f$ ) in view of the relevance of training evaluation, there is a need to create methods that make it possible to evaluate the results of applied training, since they allow to evaluate the level of learning, possible contribution to the company and the adequacy of future training.

\section{FINAL CONSIDERATIONS}

It is noticeable that in the face of a competitive economic scenario, organizations use T\&D techniques to increase the performance of people, develop skills and acquire new knowledge aimed at increasing the satisfaction of their human capital, preparing them for challenges and changes that may occur in the social and work environment. In this sense, we sought to identify the possibilities for improvements in T\&D in a food business organization from the perception of its managers. To achieve the research objective, the stages of the T\&D programs were essential for analysis, through the diagnosis, the types of training applied were identified, 
the people responsible for training, the conditions for carrying out the training, and finally, the evaluation methodologies.

It is observed that there are opportunities for improvements that can be addressed and improved in the T\&D processes of the company's employees. In view of the reports, we identified the need for investments in the training of HR managers, leaders and, above all, greater attention and preparation of employees from the industrial base is required, as this sector has a greater lack of investments. As for the development of leaders, there is a consensus on the part of managers of the need to work on communication practices between leaders and followers, aiming to improve working relationships. Finally, it is suggested to partner with the city's municipal bodies, as there is a need for technical qualification courses.

This research contributes to the academic and managerial aspects, since it presented theoretical contributions on the theme of T\&D, reaffirming the importance of thinking about actions in an integrated way with the $\mathrm{CE}$, with the purpose of meeting the strategic and operational needs of the organization. The results can help managers who experience the challenges related to T\&D in practice, contributing to the observation and description of ways to improve their processes and the development of their human capital. It is, therefore, plausible to highlight that T\&D practices enable employees to adequately assume a new job or a new activity, generating the development of new skills, essential for business sustainability, career opportunities and process improvement.

When considering the limitations, it is admitted that such deficiencies found may only be occasional, that is, they cannot be used as a rule and they do not serve as absolute parameters for other branches of the company, since the study was conducted only in this unit which is located in the interior of the state of MT, relatively distant from the main large urban, industrial and logistical centers in the country, and can portray distinct characteristics from the others. That is, the singularity of applying the research in a single company, will not allow generalizations to be made to other branches or organizations.

As a suggestion for future work, it is recommended to carry out research that addresses the managers' perception of other HR areas such as recruitment and selection, remuneration and benefits, performance management and job security. Or even, address the importance of T\&D from the perspective of employees, at the technical, administrative and operational levels, seeking to contribute to the improvement of people and processes.

\section{REFERENCES}

Amorim, W. A. C., Cruz, M. V. G., Sarsur, A. M., \& Fischer, A. L. (2015). Políticas de educação corporativa e o processo de certificação bancária: distintos atores e perspectivas. Revista Eletrônica de Administração, 21(3), p. 622-647.

Araújo, L. C. G., \& Garcia, A. A. (2009). Gestão de pessoas. estratégias e integração organizacional. (2. ed.) São Paulo: Atlas.

Azevedo, A. M. M. (2013). Gestão da sustentabilidade organizacional: inovação, aprendizagem e capital humano. Gestão \& Conexões, 2(1), 231-238.

Bagattoli, S. L., \& Muller, G. C. K. (2016). Treinamento e desenvolvimento de pessoal: agregando valor às pessoas e à organização. NAVUS - Revista de Gestão e Tecnologia, 6(2), 106-120.

Bardin, L. (2011). Análise de conteúdo. São Paulo: Edições 70.

Barrat-Pugh, L., Hodge, S., \& Smith, E. (2018). Learning and development practitioners: identity, profession and future trajectory. Asia Pacific Journal of Human Resources, early view.

Bortoluzzi, F. R., Genari, D., \& Macke, J. (2018). Capital humano nas organizações intensivas em conhecimento: desafios e perspectivas. Revista Inteligência Competitiva. 8(1), 44-79.

Botoli, W. (2017). Capacitação e desenvolvimento profissional como ferramenta de gestão: um estudo de caso no Banrisul(Trabalho de Conclusão de Curso, Universidade de Passo Fundo). Available in http://repositorio.upf.br/handle/riupf/1165

Brasil. (2019). Associação Brasileira de Indústria de Alimentos. Números no setor. Available in https://www.abia.org.br/vsn/tmp_6.aspx?id=16. 
Creswell, J. W. (2014). Investigação qualitativa e projeto de pesquisa: escolhendo entre cinco abordagens. (3. ed.) Porto Alegre: Penso.

Dutra, J. S., Dutra, T. A., \& Dutra, G. A. (2017). Gestão de pessoas. realidade atual e desafios futuros. São Paulo: Atlas.

Froehlich, C., \& Scherer, C. E. (2013). Treinamento e desenvolvimento: um estudo de caso na empresa LLV metalúrgica situada no rio grande do sul. Desenvolve - Revista de Gestão do Unilasalle, 2(2), 137-154.

Gil, A. C. (1994). Administração de recursos humanos. um enfoque profissional. São Paulo: Atlas.

Godoy, A. (1995). Pesquisa qualitativa: tipos fundamentais. Revista de Administração de Empresas, 35(3), 20 29.

Hanapiyah, Z. M., Daud, S., Abdullah, W. M. T. W., \& Sanusi, Z. M. (2018). Effect of training and development, recruitment and selection, and internal control policy on corruption risk. The Journal of Social Sciences Research, 5, 995-1006.

Hardy III, J. H., Day, E. A., \& Arthur Junior, W. (2019). Exploration-exploitation tradeoffs and informationknowledge gaps in self-regulated learning: Implications for learner-controlled training and development. Human Resource Management Review, 29(2), 196-217.

Ivancevich, J. (2008). Gestão de recursos humanos. São Paulo: McGraw-Hill.

Jalloh, A. A., Abdullahi M., \& Sesay, A. K. (2015). The impact of training and development on staff performance in tertiary educational institutions in Sierra Leone. International Journal of Management Sciences and Business Research, 4(8), 12-23.

Karolczak, M. E., \& Souza, Y. S. (2017). Recursos humanos para a economia do conhecimento na ótica da teoria do capital humano. Revista Alcance, 24(1), 66-80.

Lacombe, F. J. M. (2011). Recursos Humanos. princípios e tendências. (2. ed.) São Paulo: Saraiva.

Leite, P., \& Loft, T. (2013). Treinamento e desenvolvimento organizacional, uma ferramenta nas empresas atuais. Revista Científica Semana Acadêmica. 1(42).

Macena Neto, J. B. M., \& Mota, F. P. B. (2017). Treinamento e desenvolvimento nas organizações: estudo sobre a satisfação com o treinamento em uma instituição pública de ensino federal. Métodos e Pesquisa em Administração, 2(2), 47-61.

Marras, J. (2009). Administração de recursos humanos. do operacional ao estratégico. (13. ed.) São Paulo: Saraiva.

Marras, J. (2017a). Administração de recursos humanos. São Paulo: Saraiva.

Marras, J. (2017b). Gestão de pessoas em empresas inovadoras. São Paulo: Saraiva.

Menegon, E. M. P., \& Zambarda, A. B. (2019). Percepção de colaboradores sobre as ações de treinamentos em uma indústria têxtil. NAVUS - Revista de Gestão e Tecnologia, 9(1), 7-20.

Nafukho, F. M., Hairston, N., \& Brooks, K. (2004) Human capital theory: implications for human resource development. Human Resource Development International, 7(4), 545-551.

Otoo, F. N. K. (2018). Human resource management (HRM) practices and organizational performance: the mediating role of employee competencies. Employee Relations, 41(5), 949-970.

Rawashdeh, A. M., \& Tamimi, S. A. (2019). The impact of employee perceptions of training on organizational commitment and turnover intention an empirical study of nurses in Jordanian hospitals. European Journal of Training and Development, (4)8, 12-23.

Rosini, A. M., Alves, G. A., \& Alves, T. L. (2018). A percepção dos funcionários de uma 'instituição financeira' sobre a importância da educação corporativa (EC) para o sucesso da carreira profissional. Revista Gestão \& Planejamento, 19, 401-413.

Sá-Silva, J. R., Almeida, C. D., \& Guindane, J. F. (2009). Pesquisa documental: pistas teóricas e metodológicas. Revista Brasileira de História de Ciências Sociais, 1(1), 1-15. 
Scantamburlo, V. A., Delgado, D. S., Cavalheiro, R. T., \& Kremer, A. M. (2019). Elementos formadores do capital intelectual no contexto das pequenas e médias empresas. NAVUS - Revista de Gestão e Tecnologia, $9(2), 61-75$.

Silva, M. C., Gomes Junior, W. V., Valdati, A. B., Willerding, I. A. V., \& Lapolli, E. M. (2017). Treinamento e desenvolvimento de pessoas e seu impacto no atingimento de metas de vendas na era do conhecimento. Revista da Universidade Vale do Rio Verde, 15(2), 20-35.

Silva, S. W., Fonseca, L. R., Silva, M. R., Portugal Junior, P. S.; \& Piurcosky, F. P. (2018). Impactos do e-learning em um programa de educação corporativa. Gestão \& Conexões, 7(2), 184-202.

Souza, J., Kanaane, R., \& Fernandez, S. (2015). Treinamento e desenvolvimento: uma visão do tema nas empresas de recrutamento e seleção. Anais do V Workshop de Pós-Graduação e Pesquisa do Centro Paula Souza, São Paulo, 5, 690-699.

Souza, M. O., \& Ziviani, F. (2012). Universidade Corporativa: implantação, ferramentas e práticas. Revista Gestão \& Planejamento, 13(3), 712-727.

Toledo, G. S., \& Domingues, C. R. (2018). Produção sobre educação corporativa no brasil: um estudo bibliométrico. Revista de Gestão e Secretariado, 9(1), 108-127.

Volpe, R. A., \& Lorusso, C. B. (2009). A importância do treinamento para o desenvolvimento do trabalho. Psicologia, online, 1-8.

Yin, R. K. (2015). Estudo de Caso: planejamento e métodos. (5. ed.) Porto Alegre: Bookman.

Zanette, M. (2017). Pesquisa qualitativa no contexto da educação no brasil. Educar em Revista, 33(65), 149166. 